\title{
Clinical presentation and immune characteristics in first-lactation Holstein-Friesian cows following intramammary infection with genotypically distinct Staphylococcus aureus strains
}

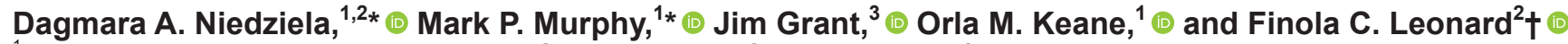 \\ ${ }^{1}$ Animal and Bioscience Department, Teagasc, Grange, Dunsany, Co. Meath, Ireland C15 PW93 \\ ${ }^{2}$ School of Veterinary Medicine, University College Dublin, Dublin 4, Ireland \\ ${ }^{3}$ Statistics and Applied Physics, Teagasc, Ashtown, Dublin 15, Ireland
}

\begin{abstract}
Staphylococcus aureus is an important cause of bovine mastitis, and intramammary infections caused by this pathogen are often characterized as mild, chronic, or persistent. The strains of Staph. aureus associated with mastitis belong to several distinct bovine-adapted bacterial lineages. Studies of host-pathogen interactions have demonstrated that significant differences exist between Staph. aureus strains and lineages in their ability to internalize and to elicit expression of chemokines and pro-inflammatory mediators in bovine cells in vitro. To determine the effect of bacterial strain on the response to intramammary infection in vivo, 14 disease-free, first-lactation cows were randomly allocated to 2 groups and challenged with Staph. aureus strain MOK023 (belonging to CC97) or MOK124 (belonging to CC151). Clinical signs of infection, as well as somatic cell count (SCC), bacterial load, IL-8 and IL-1 $\beta$ in milk, anti-Staph. aureus IgG in milk and serum, anti-Staph. aureus IgA in milk, and white blood cell populations in milk and blood were monitored for $30 \mathrm{~d}$ after the challenge. Cows infected with MOK023 generally developed subclinical mastitis, whereas cows infected with MOK124 generally developed clinical mastitis. Milk yield was reduced to a greater extent in response to infection with MOK124 compared with MOK023 in the first week of the study. Significantly higher SCC, IL-8, and IL-1 $\beta$ in milk as well as higher anti-Staph. aureus IgG and IgA in milk and anti-Staph. aureus $\operatorname{IgG}$ in serum were also observed in response to MOK124 compared with the response to MOK023. Higher proportions of neutrophils were observed in milk of animals infected with MOK124 than in animals infected with MOK023. Higher neutrophil concentra-
\end{abstract}

Received August 9, 2019.

Accepted April 27, 2020.

*These authors contributed equally to this work.

†Corresponding author: Nola.Leonard@ucd.ie tion in blood was also observed in the MOK124 group compared with the MOK023 group. Overall, the results indicate that the outcome of mastitis mediated by Staph. aureus is strain dependent.

Key words: bovine mastitis, strain-specific immune response, Staphylococcus aureus

\section{INTRODUCTION}

Mastitis is an inflammation of the mammary gland that may be clinical or subclinical and of infectious or noninfectious origin. Somatic cell count is the current industry standard for detection of subclinical bovine mastitis, mostly measured on composite milk from all 4 quarters. Regular individual cow milk recording is recommended to prevent the spread of mastitis pathogens (Brightling et al., 2009; Østerås and Sølverød, 2009; AHI, 2011). Both clinical and subclinical mastitis have been associated with significant economic losses due to the cost of veterinary intervention, discarded milk, a reduction in milk volume and quality, loss of milk premiums, and premature culling of chronically infected cows (Halasa et al., 2007). Clinical mastitis in the United States has been estimated to cost $\$ 444$ per case (Rollin et al., 2015). In Ireland, subclinical mastitis, defined as an increase in SCC from 100,000 to $>400,000$ cells $/ \mathrm{mL}$, was associated with a reduction in the value of raw milk by $€ 0.0096$ per liter and a total loss of $€ 51.3$ million per year to the Irish dairy industry (Geary et al., 2014).

Staphylococcus aureus is the most common pathogen associated with mastitis in Ireland, isolated from 23 and $21 \%$ of milk samples from clinical and subclinical cases, respectively (Barrett et al., 2005; Keane et al., 2013). It is also the main cause of mastitis in Norway (Østerås et al., 2006), Sweden (Persson et al., 2011), and the Netherlands (Barkema et al., 1998). Mastitis caused by Staph. aureus is often characterized as mild, chronic, or persistent (Bannerman et al., 2004). Reoccurrence of Staph. aureus infections after antibiotic 
treatment (Ster et al., 2017) or recovery from infection (Zadoks et al., 2001) makes this pathogen difficult to eradicate in dairy herds.

Host factors, such as cow breed or the ability of an animal to mount an immune response, have been investigated for their associations with variations in responses to Staph. aureus mastitis (Bannerman et al., 2008; Benjamin et al., 2015). Pathogen factors have also been studied, such as the ability of Staph. aureus to induce an immune response (Bannerman et al., 2004; Petzl et al., 2008; Petzl et al., 2016) or the ability of small colony variants of Staph. aureus to cause disease (Atalla et al., 2009). Both host and pathogen factors influence progression and outcome of Staph. aureus mastitis. To elucidate the molecular mechanisms of infection by Staph. aureus, in vitro studies have been conducted, investigating the immune response to Staph. aureus in bovine mammary epithelial cells (bMEC; Zbinden et al., 2014; Günther et al., 2016), bovine macrophages (Günther et al., 2016), and bovine fibroblasts (Benjamin et al., 2015). Of these studies, only 1 used more than a single Staph. aureus strain (Zbinden et al., 2014). The results of several in vitro studies, taken together, suggest that differences exist between strains of Staph. aureus in their ability to internalize within bMEC and to elicit expression of chemokines and inflammatory mediators in bMEC (Zbinden et al., 2014; Bardiau et al., 2016).

Strains of Staph. aureus can be characterized using molecular methods such as multi-locus sequence typing (Enright et al., 2000). Related sequence types (ST) are grouped into lineages or clonal complexes (CC). Irish clinical mastitis Staph. aureus isolates predominantly belong to 4 main lineages: CC71, CC97, ST136, and CC151, which account for $33,18,11$, and $33 \%$ of isolates, respectively (Budd et al., 2015). These lineages differ genotypically and phenotypically (Budd et al., 2016).

We recently investigated the interaction of multiple strains of Staph. aureus with bMEC and neutrophils in vitro (Murphy et al., 2019). Challenge of bMEC with strains from CC97 resulted in significant upregulation of several cytokines and chemokines, with production of chemotactic factors sufficient to attract neutrophils. In contrast, challenge of bMEC with strains belonging to CC151 resulted in modest upregulation of cytokine and chemokine expression and was insufficient to attract neutrophils. Other studies have also indicated differing abilities among strains and lineages of Staph. aureus to interact with bovine cells in vitro, including lower expression of inflammatory mediators in bMEC in response to CC151 strains compared with strains from other Staph. aureus lineages (Zbinden et al., 2014; Budd et al., 2016) and differences among CC5, CC8,
CC97, and CC151 strains in their ability to invade bMEC or form biofilm (Bardiau et al., 2016; Budd et al., 2016). However, studies that compare responses to different Staph. aureus strains in vivo are lacking. Information about outcomes of IMI with strains belonging to CC151 is also limited. Only 2 in vivo studies with strain RF122 (which belongs to CC151) have been published to date (Wilson, 2011; Wilson et al., 2018). Because CC151 is an important lineage causing mastitis in Ireland (Budd et al., 2015) and worldwide (Smith et al., 2005; Schlotter et al., 2012; Barlow et al., 2013), more in-depth studies are necessary.

The aim of this study was to assess the effect of Staph. aureus strain on the immune response to IMI and on disease presentation in vivo. Two strains were selected based on their in vitro characteristics (Murphy et al., 2019). These 2 strains were used to challenge 14 Holstein-Friesian cows, and the response to infection was studied for $30 \mathrm{~d}$.

\section{MATERIALS AND METHODS}

\section{Ethics Statement}

All procedures involving animals received approval from the University College Dublin (Dublin, Ireland) Animal Research Ethics Committee (protocol number Leonard AREC 16 44) and project authorization from the Health Products Regulatory Authority (Dublin, Ireland; authorization number AE18982/P108). Animal studies were compliant with all applicable provisions established by European Union Directive 2010/63/ EU (http://data.europa.eu/eli/dir/2010/63/oj). All animals were handled in accordance with good clinical practices, and all efforts were made to minimize suffering.

\section{Animals and Study Design}

Fourteen first-lactation Holstein-Friesian cows were purchased from 2 commercial farms, with 10 cows sourced from farm 1 and 4 from farm 2 . The number of animals required was based on power calculations approved by the University College Dublin Animal Research Ethics Committee and as outlined under Statistical Analysis. Source herds were selected based on milk quality, with bulk tank SCC $<200,000$ cells/ $\mathrm{mL}$. Animals were selected when composite milk SCC was $<100,000$ cells $/ \mathrm{mL}$ (based on their first and only milk record) and were seronegative or vaccinated for leptospirosis, salmonellosis, and Johne's disease. The low SCC status of the cows was confirmed after purchase, with all quarters $<100,000$ cells $/ \mathrm{mL}$. Cows were maintained outdoors at the University College Dublin 
research farm (Lyons Estate, Co. Meath, Ireland), had at least 2 wk to acclimate to the herd before intramammary challenge, and were fed a diet of grass and silage ad libitum and $3 \mathrm{~kg}$ of a standard barley-based concentrate containing $15 \% \mathrm{CP}$ twice a day during milking. The cows were milked twice a day, at 0830 and $1600 \mathrm{~h}$ in a 40-point rotary milking parlor (Dairymaster, Cincinnati, OH) with on-platform teat sprays and automatic cluster removal and milk yield recording. On the morning of challenge, cows were on average 146 DIM, ranging from 127 to 169 DIM. Individual animal information is included in Supplemental Table S1 (https://doi.org/10.3168/jds.2019-17433).

\section{Preparation of Staph. aureus Inoculum}

Two strains were chosen for this study, based on in vitro studies of host cell internalization and immune response (Murphy et al., 2019): MOK023 (ST3170, CC97) and MOK124 (ST151, CC151). The strains were isolated from cases of clinical mastitis (Keane et al., 2013; Budd et al., 2015), and their genomes were sequenced (MOK023 accession number SRS775827; MOK124 accession number SRS2841713). A pilot study established $500 \mathrm{cfu}$ as an appropriate dose of MOK124 to establish mild clinical mastitis in first-lactation cows, as defined by an increase in SCC between 500,000 and 1,000,000 cells $/ \mathrm{mL}$ and visible clots in milk, with the absence of other clinical signs of disease such as a markedly inflamed quarter, pyrexia, inappetence, or listlessness. Bacteria were cultured for $18 \mathrm{~h}$ in Trypticase soy broth (TSB, Aquilant Scientific, Dublin, Ireland). After overnight culture, bacteria were centrifuged at 4,000 $\times g$ for $10 \mathrm{~min}$ and subsequently washed twice with PBS (Gibco, Waltham, MA). The optical density at $600 \mathrm{~nm}$ was adjusted to 1 , and serial dilutions were performed in PBS to obtain $500 \mathrm{cfu} / 400 \mu \mathrm{L}(1,250$ $\mathrm{cfu} / \mathrm{mL})$. The inoculum was plated in 9 replicates to confirm the bacterial count and stored at $4^{\circ} \mathrm{C}$ overnight before intramammary challenge.

\section{Intramammary Bacterial Challenge}

At the time of challenge the cows were on average $2 \mathrm{yr}$ and 4 mo old (between $2 \mathrm{yr}$ and 2 mo and $2 \mathrm{yr}$ and 6 mo old). Animals were randomly assigned to be challenged with one of the Staph. aureus strains, with the assignment blocked by source farm and multiple replications of treatment per farm. All investigators were blinded to treatment assignment. No significant differences were detected in pre-challenge SCC or DIM between the 2 groups (Table 1 ). No bacteria were recovered from quarter milk samples collected from all cows immediately before challenge $(10 \mu \mathrm{L}$ of milk plated on blood agar), and all quarters had SCC $<100,000$ cells/ $\mathrm{mL}$. Teats were cleaned with ethanol and chlorhexidine teat wipes (Teisen, Bradley Green, UK), and Staph. aureus (500 cfu in $400 \mu \mathrm{L}$ of PBS) was inoculated into the teat sinus of the left hind quarter of each cow using a 1-mL syringe and an 18-gauge hypodermic needle cut to $17 \mathrm{~mm}$ and filed smooth. The same volume of PBS was inoculated into the right front quarter, as a control. Following inoculation, $50 \mu \mathrm{L}$ of the remaining bacterial solutions were plated on Trypticase soy agar (TSA; Lab M, Heywood, UK) in 9 replicates; colonies were counted to determine the actual inoculum used for challenge.

\section{Sampling and Clinical Scoring}

Before milk sampling, teats were cleaned with ethanol and chlorhexidine teat wipes (Teisen), and foremilk was stripped from each quarter. Milk appearance was recorded as follows:

a. Clots + : a few small flecks easily discernible in normal colored milk;

b. Clots ++ : clots approximately the size of rice grains in slightly discolored milk;

c. Clots +++ : large clots in cream-colored milk.

Table 1. Mean DIM and SCC values for cows challenged with Staphylococcus aureus strains MOK023 ( $\mathrm{n}=7)$ or MOK124 $(\mathrm{n}=7)$; differences between groups calculated via 2-tailed unpaired $t$-test ${ }^{1}$

\begin{tabular}{|c|c|c|c|}
\hline Item & MOK023 (CC97) & MOK124 (CC151) & $P$-value \\
\hline DIM & 149 & 143 & 0.46 \\
\hline DIM range & $127-169$ & $128-165$ & NA \\
\hline Composite $\mathrm{SCC}^{2}($ cells $/ \mathrm{mL})$ & 41,429 & 44,000 & 0.72 \\
\hline Left hind quarter $\mathrm{SCC}^{3}$ (cells $\left./ \mathrm{mL}\right)$ & 12,857 & 12,286 & 0.3 \\
\hline Daily milk yield ${ }^{4}(\mathrm{~kg})$ & 16.8 & 16.9 & 0.92 \\
\hline
\end{tabular}


Milk samples were taken into 20 -mL sterile universal containers and subsequently used for bacterial count, SCC, and differential cell count. Blood samples were taken from the neck or tail vein into EDTA (Vacuette, Greiner Bio-One, Kremsmünster, Austria) and serum tubes (Vacutainer, BD, Swindon, UK). Rectal temperature, milk yield, and appetite were also recorded. Milk sampling took place at morning and afternoon milking for the first $3 \mathrm{~d}$, every morning for the following $3 \mathrm{~d}$, and 3 times per week (Monday, Wednesday, Friday) for 3 wk thereafter. Blood samples and rectal temperature measurements were taken at the same frequency as milk samples for the first week, and then on the first sampling day of each week in the following weeks.

\section{Bacteriology}

Following Staph. aureus inoculation, milk from the challenged quarter was serially diluted to $10^{-6}$, and 50 $\mu \mathrm{L}$ of each dilution plated on duplicate TSA plates. The number of colonies was enumerated on the plates from the 2 dilutions, with approximately 30 to 300 colonies per plate. Milk $(10 \mu \mathrm{L})$ from each of the 4 quarters was also streaked on sheep blood TSA plates to confirm Staph. aureus morphology for the challenged quarters and lack of contaminating organisms in all quarters. Suspect colonies were plated on mannitol salt agar to presumptively identify Staph. aureus. Colonies exhibiting typical Staph. aureus morphology were selected from TSA plates from each cow once a week and stored in TSB with $20 \%$ glycerol; stored isolates were subsequently confirmed as Staph. aureus based on their morphology on blood agar and mannitol salt agar, as well as the presence of the nuc gene and a positive tube coagulase test. Strain identity was presumptively identified by MIC testing of a panel of antibiotics using VITEK 2 (Biomérieux UK Limited, Basingstoke, UK) and comparison with the antibiotic resistance profiles of MOK023 and MOK124. To validate presumptive strain identification, the genetic profiles of 6 representative isolates were also confirmed by whole-genome sequencing on an Illumina MiSeq (Illumina, San Diego, CA). The sequenced isolates were randomly chosen from different cows.

\section{SCC}

Antimicrobial broad-spectrum microtabs (Advanced Instruments Inc., Norwood, MA) were added to approximately $20 \mathrm{~mL}$ of milk following bacteriological sampling. Somatic cells were counted using a Bentley Somacount 300 (Bentley Instruments Inc., Chaska, $\mathrm{MN})$. Milk samples with values above the counting capacity of the instrument $\left(9.99 \times 10^{6}\right.$ cells $\left./ \mathrm{mL}\right)$ were diluted 1/10 using Maximum Recovery Diluent (Oxoid, CM0733, Waltham, MA) and re-counted. Average SCC was defined as the average of the quarter-level SCC values.

\section{Differential Counts of Blood and Milk Cells}

To determine differential cellular compositions, milk smears were prepared using $8 \mu \mathrm{L}$ of milk. Slides were rapidly dried using a fan and stained with Speedy-Diff (Clin-Tech Ltd., Guildford, UK) differential stain according to the manufacturer's protocol. Cell identification was performed in various locations on the slide, and 100 cells (or as many as were present if $<100$ ) were identified. Cells were identified as neutrophils, lymphocytes, large mononuclear cells, or unknown cells. Blood samples were analyzed for numbers of monocytes, lymphocytes, neutrophils, basophils, and eosinophils on an Advia 2120 hematology system (Siemens, Frimley, UK) within $6 \mathrm{~h}$ of sample collection.

\section{ELISA}

Milk was defatted by centrifugation at $800 \times g, 15^{\circ} \mathrm{C}$, for $10 \mathrm{~min}$. The top fat layer was discarded, and the supernatant was stored in $1-\mathrm{mL}$ aliquots at $-20^{\circ} \mathrm{C}$. For quantification of cytokines, $100 \mu \mathrm{L}$ of defatted milk was assayed by sandwich ELISA for the presence of IL-1 $\beta$ (Thermo Fisher Scientific, Waltham, MA) and IL-8 (Cronin et al., 2015), per instructions. All samples were assayed in duplicate, and values below the limit of detection $(31.25 \mathrm{pg} / \mathrm{mL}$ for IL- $1 \beta$ and $31 \mathrm{pg} / \mathrm{mL}$ for IL-8) were set to zero.

Anti-Staph. aureus IgG and IgA in milk and antiStaph. aureus IgG in serum were also quantified by ELISA. The protocol was adapted from Benjamin et al. (2015): MOK023 and MOK124 were grown in TSB overnight, washed twice with PBS, and resuspended in TSB to yield $1 \times 10^{9} \mathrm{cfu} / \mathrm{mL}$. Bacteria were heatinactivated by incubating at $70^{\circ} \mathrm{C}$ for $45 \mathrm{~min}$, with vigorous shaking every 10 min. Wells of 96-well ELISA plates were coated with either $100 \mu \mathrm{L}$ of bacterial solution (MOK023 or MOK124) diluted $1 / 10$ in $0.05 M$ bicarbonate buffer (Thermo Fisher Scientific) or 100 $\mu \mathrm{L}$ of $0.05 M$ bicarbonate buffer (a blank well), and incubated at $4^{\circ} \mathrm{C}$ overnight. Plates were washed 3 times with $300 \mu \mathrm{L}$ of Dulbecco phosphate-buffered saline (DPBS; Gibco)-0.05\% Tween-20 (wash buffer; SigmaAldrich, St. Louis, MO), and $100 \mu \mathrm{L}$ of blocking buffer (2\% skim milk powder solution in DPBS) was added to each well and incubated for $1 \mathrm{~h}$ at room temperature. Following 3 more washes, $100 \mu \mathrm{L}$ of sample (for $\operatorname{IgG}$, defatted milk diluted $1 / 1,000$ or serum diluted $1 / 10,000$ in DPBS; for IgA, defatted milk diluted 1/10 in DPBS) 
was added and incubated at room temperature for $1 \mathrm{~h}$. A calibrator and a nonspecific binding well (blocking buffer instead of milk sample) were included with each plate. Plates were washed 3 times. Subsequently, 100 $\mu \mathrm{L}$ of a horseradish peroxidase conjugated goat antibovine IgG antibody solution (Invitrogen, Carlsbad, $\mathrm{CA}$ ) diluted $1 / 40,000$ in DPBS or $100 \mu \mathrm{L}$ of a horseradish peroxidase conjugated sheep anti-bovine $\operatorname{IgA}$ (Bio-Rad, Hercules, CA) diluted 1/40,000 was added and incubated at room temperature for $1 \mathrm{~h}$. Lastly, after washing, 3,3',5,5'-tetramethylbenzidine substrate (Thermo Fisher Scientific) was added to each well, and the reaction was stopped with $0.16 \mathrm{M} \mathrm{H}_{2} \mathrm{SO}_{4}$ (Thermo Fisher Scientific) after $15 \mathrm{~min}$. The absorbance at 450 $\mathrm{nm}$ was determined. Resulting absorbance values were adjusted by subtracting the nonspecific binding well values from each plate and subsequently calibrator corrected using Factor software (Ruijter et al., 2006).

\section{Statistical Analysis}

The experiment was designed with power 0.8 to detect a $0.5 \mathrm{log}$ difference in the mean infected quarter SCC over time (from 100,000 cells/mL to 500,000 cells/ $\mathrm{mL}$ ), which required 6 cows per treatment. Sample size was calculated using methods based on the formula for comparison of 2 groups based on a continuous outcome variable: $\mathrm{n}=2 \sigma^{2}\left(\mathrm{z}_{\alpha / 2}+\mathrm{z}_{\beta}\right)^{2} /\left(\mu_{1}-\mu_{2}\right)^{2}$, where $\mathrm{n}=$ sample size, $\sigma=$ standard deviation of the population, $\mathrm{z}_{\alpha / 2}=$ standard normal deviate for the desired level of significance, $z_{\beta}=$ standard normal deviate for the desired power and $\mu_{1}-\mu_{2}=$ the difference between the 2 population means to be compared. Calculations were performed using a web app (http://homepage .divms.uiowa.edu/ rlenth/Power/), and percentiles of the $t$ distribution replaced the percentiles of the normal distribution. One additional cow per treatment was included as a contingency. It was further calculated that 4 cows per treatment would have power 0.8 to detect a $0.7 \mathrm{log}$ difference. Differences in DIM, as well as pre-challenge SCC and milk yield values between groups, were calculated with a 2 -tailed unpaired $t$-test. Contingency tables were created for the presence of clots in milk, swelling of quarter, and development of fever (temperature above $39.5^{\circ} \mathrm{C}$ ). The data analyzed were the outcomes at the end of the trial, and outcome was presence of the sign at any point during the trial. Differences between groups were assessed using Fisher's exact test in GraphPad Prism (version 7, La Jolla, CA). Repeated measures ANOVA was performed using a MIXED procedure in SAS (version 9.4, SAS Institute Inc., Cary, NC) to compare strain-dependent differences. The following transformations were used to satisfy the distributional requirements of ANOVA: $\log _{10}(\mathrm{x}+1)$ for bacterial load, SCC, and percentage of large mononuclear cells in milk; sqrt(x) for IL-8 in infected and control quarters; and $\log _{10}(10 \mathrm{x}+1)$ for IgG in serum and for percentage of milk lymphocytes. Milk yield, percentage of neutrophils in milk and blood, and all other hematology measurements, as well as the anti-Staph. aureus IgG and IgA concentration in milk, were untransformed. The initial model fitted for each variable included effect of strain, time, and source farm, pre-infection value of the variable as a covariate, and all interactions, and relevant quadratic terms to detect curvature. The model was then sequentially reduced by eliminating all covariate terms with $P>0.05$. Tukey's post-hoc multiple comparison test was applied as appropriate. Average milk yields for each cow from the week before infection were used as the pre-infection values for milk yield, due to large day-to-day variations in individual cows. Correlations among repeated measurements across time between strains were modeled using the appropriate covariance structures for each variable analyzed. For effects with large degrees of freedom, $P$-values were liberally interpreted $(P<0.15)$ so as not to miss any comparisons of interest (Snedecor and Cochran, 1989, p. 305). The procedures outlined would be severely biased for IL-1 $\beta$, as this analyte was not detected in $85 \%$ of samples. Consequently, this variable was analyzed as a binomial, presence (1) or absence (0) of IL-1 $\beta$, and analyzed for the probability of "IL1 $\beta=1$ " using a LOGISTIC model in SAS, with strain, farm, and time as fixed effects, and a Firth's penalized likelihood approach to address issues of separability and small sample size. Correlations between variables were also measured using a Pearson correlation coefficient.

\section{RESULTS}

\section{Clinical Signs}

For 2 cows challenged with MOK023 and 1 cow challenged with MOK124, infection did not establish, and these cows were excluded from our results. Differences in disease presentation between groups infected with the 2 strains were observed, and cows infected with MOK023 exhibited fewer clinical signs (Table 2). Clots in milk were first observed at $31 \mathrm{~h}$ post-infection (hpi) in the MOK124 group, whereas in the MOK023 group, clots were first observed at 79 hpi (Supplemental Figure S1A, https://doi.org/10.3168/jds.2019-17433). The highest rectal temperature recorded in a cow in the MOK124 group was $41.2^{\circ} \mathrm{C}$ at $24 \mathrm{hpi}$; by contrast, the maximum rectal temperature recorded in an individual cow from the MOK023 group was $39.2^{\circ} \mathrm{C}$ at $7 \mathrm{hpi}$. A plot of rectal temperature over time is presented in 
Table 2. Signs of clinical mastitis after intramammary challenge with Staphylococcus aureus strains MOK023 or MOK124; differences between groups assessed using Fisher's exact test

\begin{tabular}{lccc}
\hline Clinical sign & MOK023 (CC97) & MOK124 (CC151) & $P$-value \\
\hline Clots in milk & $3 / 5$ & $6 / 6$ & 0.1818 \\
Swelling of quarter & $0 / 5$ & $6 / 6$ & 0.0022 \\
Temperature above $39.5^{\circ} \mathrm{C}$ & $0 / 5$ & $3 / 6$ & 0.1818 \\
\hline${ }^{1} \mathrm{CC}=$ clonal complex. & & \\
${ }^{2}$ To be counted as positive, the clinical sign was observed at least once.
\end{tabular}

Supplemental Figure S1B (https://doi.org/10.3168/jds .2019-17433).

Two cows (1776 and 1920) from the MOK124 group developed severe clinical mastitis and required treatment. Pyrexia was recorded in cow 1776 at $24 \mathrm{hpi}$; severe clotting of milk was observed at $31 \mathrm{hpi}$, and the udder was swollen, hot, and painful. Milk from the control quarter was also clotted. A decrease in appetite was also observed at 31 and 48 hpi. Antibiotic (amoxicillin-clavulanate) was administered to the infected and control quarters at $31 \mathrm{hpi}$ and $48 \mathrm{hpi}$, and subsequently systemic antibiotic (tylosin) and an anti-inflammatory drug (ketoprofen) were administered for $3 \mathrm{~d}$. Despite treatment, the left hind quarter became gangrenous, with partial sloughing of the tissue by approximately 2 mo post-infection, although systemic signs abated and the cow's appetite returned to normal at $79 \mathrm{hpi}$. Cow 1920 presented with fever at $24 \mathrm{hpi}$, with severe clots in milk and slight swelling of quarter at $48 \mathrm{hpi}$. The fever resolved by $72 \mathrm{hpi}$; however, udder swelling and severe clotting of milk persisted, and a slight decrease in appetite was observed at 55, 72, and $79 \mathrm{hpi}$. The cow was treated intramammarily in the infected quarter with amoxicillin-clavulanate at $120 \mathrm{hpi}$, although bacteria were recovered after antibiotic treatment until the end of the study. Swelling of the infected quarter was last observed at $336 \mathrm{hpi}$, and clots in milk were last recorded at $600 \mathrm{hpi}$. Both cows were removed from the trial after antimicrobial treatment.

\section{Bacteriology}

Bacteria were not recovered from any quarter before intramammary challenge. Plating of the bacterial suspensions after intramammary challenge indicated that the cows received approximately $1.73 \times 10^{2} \mathrm{cfu}$ of MOK023 and $5.83 \times 10^{2} \mathrm{cfu}$ of MOK124. Infection was not established in 2 cows from the MOK023 group and in 1 cow from the MOK124 group.

Staphylococcus aureus was recovered from milk of all infected animals by $48 \mathrm{hpi}$. Differences were observed in recovery of the 2 strains in milk over time; however, bacteria were recovered consistently from all infected quarters in the MOK023 group until the end of the trial, and intermittent shedding of bacteria was observed in infected animals from the MOK124 group, with inconsistent recovery of the pathogen in milk (Supplemental Table S2, https://doi.org/10.3168/jds .2019-17433). Presumptive Staph. aureus were intermittently recovered from the control quarter of cow 1776 starting at $7 \mathrm{hpi}$. The PBS-infused quarters and nonchallenged quarters of all other animals remained free of detectable pathogens throughout the study.

We detected significant difference between groups $(P$ $=0.01)$ and a significant group $\times$ time interaction $(P$ $=0.002)$ in bacterial load in the infected animals. The MOK124 bacterial load was significantly higher than that of MOK023 at 24 and $31 \mathrm{hpi}$, whereas the MOK023 bacterial load was higher than that of MOK124 between 216 and 504 hpi (Figure 1A). Maximum bacterial load in the MOK023 group was observed at $168 \mathrm{hpi}$ and reached $4.2 \times 10^{4} \mathrm{cfu} / \mathrm{mL}$, whereas the MOK124 group bacterial load peaked at $24 \mathrm{hpi}$ at $7.5 \times 10^{4} \mathrm{cfu} / \mathrm{mL}$. Data for bacterial load and other selected variables for all cows, including the uninfected animals, is presented in Supplemental Figure S2 (https://doi.org/10.3168/ jds.2019-17433).

Antibiotic resistance profiles from a total of 42 isolates taken from each infected cow from each week of the study were consistent with the profiles of their respective challenge strain, MOK023 or MOK124, suggesting that cows were infected with the correct strain for the duration of the study. Whole-genome sequencing of 6 isolates, each from a different cow, confirmed that the sequenced isolates matched the appropriate challenge strain.

\section{Milk Yield}

Milk yield dropped by $20 \% 1 \mathrm{~d}$ post-infection and by $35 \% 2 \mathrm{~d}$ post-infection in the MOK124 group, relative to pre-infection levels, and returned to pre-infection levels by $10 \mathrm{~d}$ post-infection (Figure 1B). In contrast, milk yield of animals infected with MOK023 remained relatively unchanged. A group $\times$ time interaction $(P$ $=0.002)$ in daily milk yield was detected. Examination of the interaction means showed an overall effect in line with the main effect $P$-value $(P=0.03)$. We 
also detected a significant source farm effect $(P=$ $0.0003)$. The effect of strain depended on pre-infection milk yield $(P=0.0007)$, so comparisons were made at several values of initial milk yield, and infection with MOK124 was found to result in a greater drop in milk yield in higher-producing cows.

\section{$\operatorname{SCC}$}

At challenge, SCC of all quarters was below 50,000 cells/mL, except for the left hind quarter of cow 603, which was 64,000 cells/mL (Supplemental Table S1, https://doi.org/10.3168/jds.2019-17433). Infected quarter SCC in the MOK124 group increased rapidly and reached much higher values than that in the MOK023 group (Figure 2A). The infected quarter SCC values increased in both groups between 31 and 79 hpi. Maximum SCC in the MOK023 group reached a local peak of $4.07 \times 10^{5}$ cells $/ \mathrm{mL}$ at 79 hpi and a maximum of $6.1 \times 10^{5}$ cells $/ \mathrm{mL}$ at 552 hpi. In the MOK124 group, maximum infected quarter SCC was $1.5 \times 10^{7}$ cells/ $\mathrm{mL}$ at 55 hpi. By 96 hpi SCC in the MOK023 group stabilized, whereas the SCC of MOK124-infected animals continued to decrease. The MOK023-group SCC remained $<400,000$ cells $/ \mathrm{mL}$ from $96 \mathrm{hpi}$ until the end of the study, except for 504 and 552 hpi. The MOK124group SCC reached a low value of $1.6 \times 10^{5}$ cells $/ \mathrm{mL}$ at $336 \mathrm{hpi}$ but continued to fluctuate, reaching $1.7 \times 10^{6}$ cells $/ \mathrm{mL}$ at $600 \mathrm{hpi}$ and $4.9 \times 10^{5}$ cells $/ \mathrm{mL}$ at 696 hpi.

A significant difference was detected in infected quarter SCC between groups $(P=0.0001)$, with a group $\times$ time interaction $(P=0.005)$. Significant differences were found in SCC between groups from 24 to $216 \mathrm{hpi}$ (Figure 2A). The SCC of PBS-infused quarters was also significantly different between groups (Figure 2A).

Average SCC values were at a maximum 491,000 cells/mL in the MOK023 group at 504 hpi and 4,300,000 cells/mL in the MOK124 group at 79 hpi. Average SCC in the MOK023 group also had a local peak at $79 \mathrm{hpi}$ and was 380,000 cells/mL. Most average SCC values in MOK023-infected cows were $<200,000$ cells/ $\mathrm{mL}$, but in the MOK124 group almost all cows had average SCC $>400,000$ cells/mL between 31 and 216 hpi (Supplemental Table S3, https://doi.org/10.3168/ jds.2019-17433).

\section{Cytokines in Milk}

Pre-infection, the concentration of IL-8 in milk of infected and control quarters was low; however, IL-8 concentration increased post-infection. Maximum IL-8 in the infected quarters was observed at 55 hpi for the MOK124 group $(2,330 \mathrm{pg} / \mathrm{mL})$. Concentration of IL-8 in milk of animals from the MOK023 group had a local

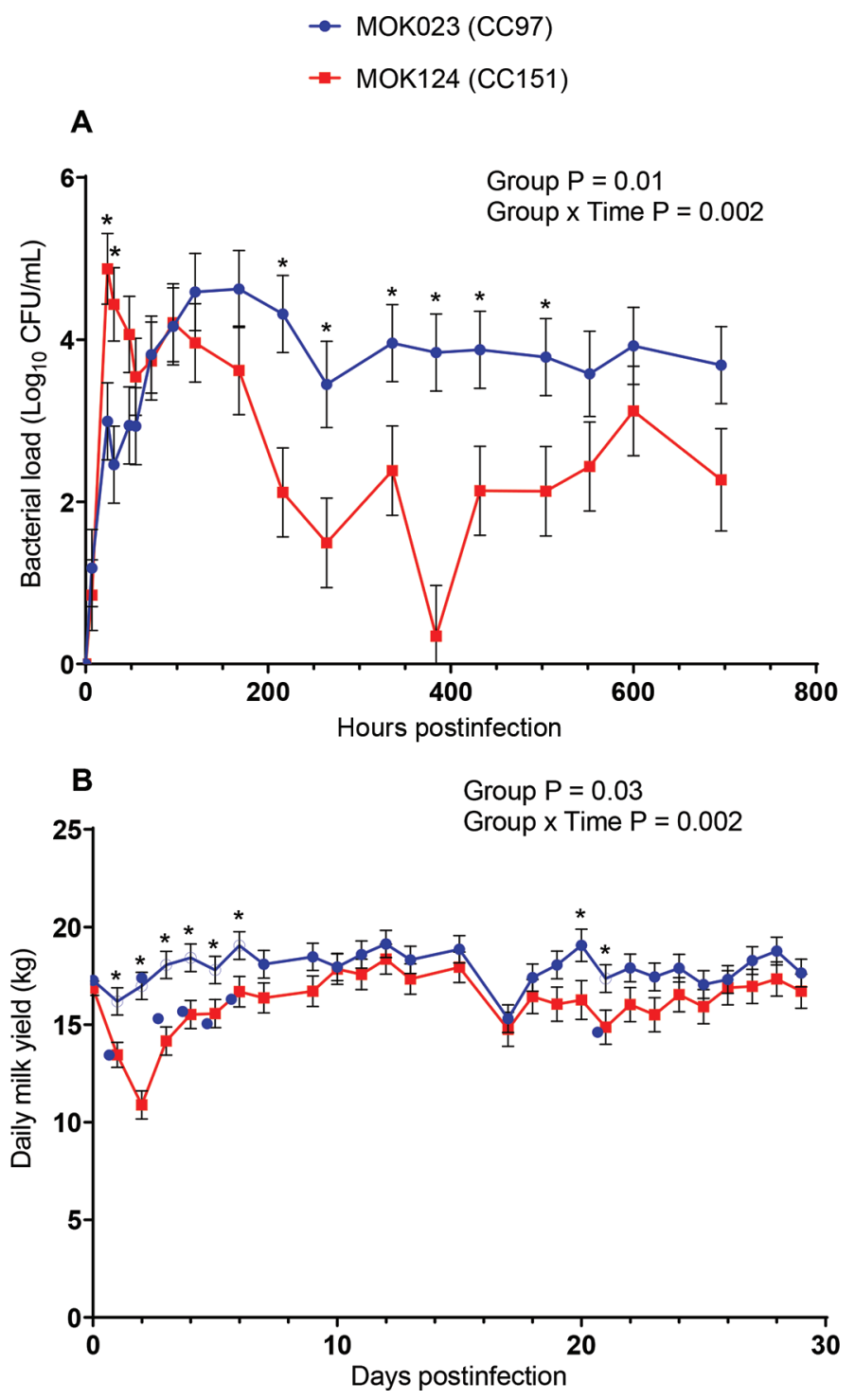

Figure 1. Bacterial load in infected quarters (A) and cow-level daily milk yield (B; LSM \pm SEM) after infection with Staphylococcus aureus strain MOK023 (blue circles) or MOK124 (red squares). CC $=$ clonal complex. Data were analyzed using a MIXED model in SAS (SAS Institute Inc., Cary, NC) with time as a repeated measure. Overall $P$-values for between-group differences and for the group $\times$ time interaction are denoted on the graph. Significant differences $(P<$ 0.05 ) between groups at each time point are marked with *.

peak at $31 \mathrm{hpi}(170 \mathrm{pg} / \mathrm{mL})$ but reached its maximum value at $504 \mathrm{hpi}(610 \mathrm{pg} / \mathrm{mL})$.

We detected a group $\times$ time interaction in IL- 8 concentration in milk from infected quarters $(P=0.0003$; Figure 2B). Significant differences between groups were observed between 24 and $168 \mathrm{hpi}$. These differences were in parallel with differences in SCC between the 2 groups. A significant correlation between IL- 8 and SCC in the infected quarter was observed $(\mathrm{r}=0.6, P=1.6$ $\left.\times 10^{-11}\right)$. An overall group difference $(P<0.0001)$ and 
a farm effect on IL-8 in infected quarters $(P=0.004)$ were also detected. Although infection with MOK124 resulted in a higher IL-8 concentration in milk than did infection with MOK023 for cows from both farms, the magnitude of the difference between groups was greater for animals from farm 2 .

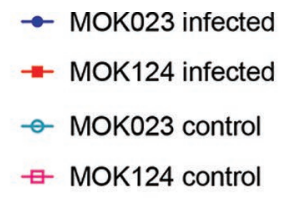

A
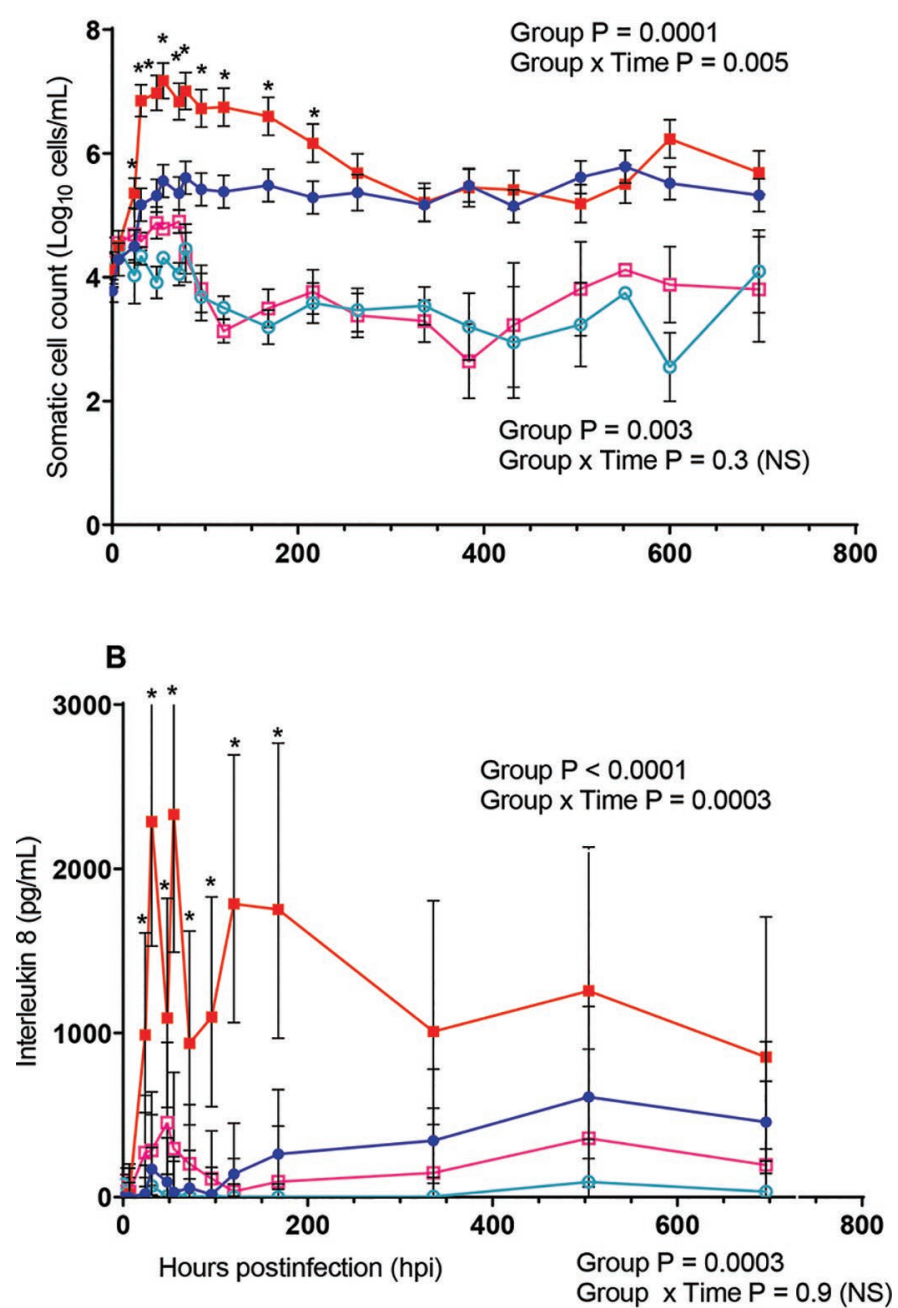

Figure 2. Effects of intramammary infection with Staphylococcus aureus strain MOK023 (blue circles) or MOK124 (red squares) on $\mathrm{SCC}(\mathrm{A} ; \mathrm{LSM} \pm \mathrm{SEM})$ in infected quarters (filled symbols) and PBSinfused quarters (empty symbols), and quarter-level IL-8 in milk (LSM $\pm 95 \%$ CI; B). Levels of IL-8 were determined via ELISA. Data were analyzed using a MIXED model in SAS (SAS Institute Inc., Cary, NC) with time as a repeated measure. Overall $P$-values for between-group differences and for the group $\times$ time interaction are denoted on the graph, with the comparison for infected quarters shown above the plot and the comparison for control quarters below the plot. Significant differences between groups $(P<0.05)$ at each time point are marked with *.

Journal of Dairy Science Vol. 103 No. 9, 2020
Significant differences in IL-8 secretion in PBS quarters also occurred (Figure 2B), with a significant group $\times$ farm interaction $(P<0.0001)$, an overall group difference $(P=0.0003)$, and a farm effect $(P=0.001)$. We found that IL-8 was higher in control quarters of the MOK124 group than in the control quarters of the MOK023 group for cows from farm 2 only; no significant difference was detected between groups for animals from farm 1.

The IL-1 $\beta$ concentration in milk was determined at $0,24,48,55,72$, and 168 hpi. There was no detectable IL-1 $\beta$ in milk from any cow before infection, and IL$1 \beta$ was not detectable in milk from cows infected with MOK023; however, it was detected in milk from some but not all cows infected with MOK124 from 24 hpi ( $P$ $=0.006$; data not shown).

\section{Differential Cell Counts}

Due to the low number of somatic cells in uninfected milk, time 0 and control quarters were excluded from statistical analysis. Post-infection milk somatic cells were primarily neutrophils, which comprised 80 to $89 \%$ of somatic cells in the MOK124 group and 41 to $69 \%$ of somatic cells in the MOK023 group (Figure 3A). Infection with MOK124 resulted in a significantly higher proportion of neutrophils in milk than did infection with MOK023 $(P<0.0001)$; this effect was more pronounced in animals from farm 2. No differences were detected between groups in the proportion of large mononuclear cells or lymphocytes in milk.

Neutrophil concentration in blood was also higher in MOK124-infected animals $(P=0.005$; Figure 3B), in particular at 55, 72, and 336 hpi. Maximum neutrophil concentration was observed at $31 \mathrm{hpi}$ for MOK023infected animals and 72 hpi for MOK124-infected animals: $3.38 \pm 0.65 \times 10^{3}$ and $4.76 \pm 0.63 \times 10^{3}$ cells/ $\mu \mathrm{L}$, respectively.

Neutrophil counts above and below the normal range of 1.7 to $6.0 \times 10^{3}$ cells $/ \mu \mathrm{L}$ (Roland et al., 2014) were observed in individual cows. In particular, neutrophil counts below $1.7 \times 10^{3}$ cells $/ \mu \mathrm{L}$ were observed in cows 1776 and 1920 on the morning of challenge. Other hematology measurements, including white blood cell counts, were not significantly different between the 2 groups.

\section{Anti-Staph. aureus Antibody Levels in Milk and Serum}

Samples were tested for the presence of anti-Staph. aureus IgG in milk and serum and anti-Staph. aureus IgA in milk by coating an ELISA plate with heat-inactivated MOK023 or MOK124. All samples were tested 
against antigen prepared from both strains, and similar results were obtained for serum IgG as well as for milk IgA and IgG. Data generated from plates coated with MOK124 were used for statistical analysis, because MOK124 does not express protein A on its cell surface (Budd et al., 2015).

Infection with MOK124 resulted in a higher Staph. aureus-specific $\operatorname{IgG}$ concentration in milk $(P=0.002$;
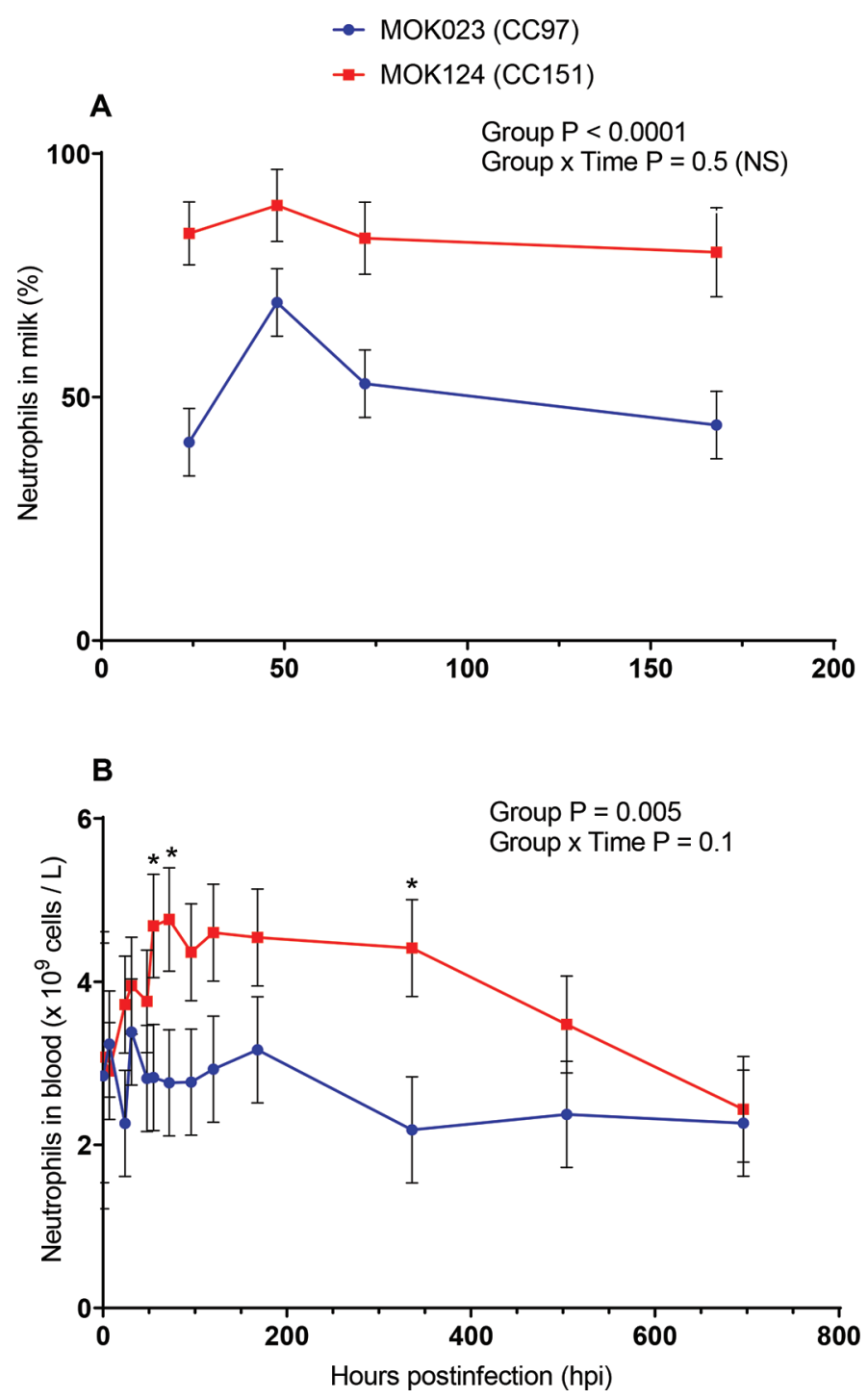

Figure 3. Effects of intramammary infection with Staphylococcus aureus strain MOK023 (blue circles) and MOK124 (red squares) on the proportion of neutrophils in milk from infected quarters (A) and on the number of circulating blood neutrophils (B; LSM \pm SEM). CC $=$ clonal complex. Neutrophils in milk were counted on microscope slides stained with a Speedy-Diff (Clin-Tech Ltd., Guildford, UK) stain. Neutrophils in blood were determined by a blood differential count on an Advia 2120 (Siemens, Frimley, UK). Data were analyzed using a MIXED model in SAS (SAS Institute Inc., Cary, NC) with time as a repeated measure. Overall $P$-values for between-group differences and for the group $\times$ time interaction are denoted on the graph.
Figure 4A). A significant group $\times$ time interaction occurred $(P=0.0002)$, with significant differences between anti-Staph. aureus IgG concentration observed between 72 and 696 hpi. Maximum antibody titers for both groups were achieved at $336 \mathrm{hpi}$, and the antibody titer in MOK124-infected cows was 3.7-fold higher than that of the MOK023 group at that time point.

Anti-Staph. aureus IgG concentration in serum was examined using the same method (Figure 4B). We detected a significant group $\times$ time interaction $(P<$ $0.0001)$, with significant differences between infecting strains observed at 48,72, 120, and between 336 and $696 \mathrm{hpi}$, and no overall group difference $(P=0.4)$ but a significant farm effect $(P<0.0001)$. A group $\times$ farm effect was also detected $(P=0.003)$, with higher antiStaph. aureus serum IgG in MOK124-infected cows than in MOK023-infected cows for farm 1. For farm 2, data points that would be expected to show a significant difference were missing. Maximum antibody titers in serum were achieved at 336 hpi for both groups, with anti-Staph. aureus IgG higher at 336 hpi than at 0 hpi, although only significantly so for the MOK124 group. The antibody titer in the MOK124 group was 1.6-fold higher than in the MOK023 group at that time point.

When assessing the anti-Staph. aureus IgG antibody titer data for individual animals, it was observed that cows from farm 2 had the lowest antibody titers in serum, both pre- and post-infection. We further observed that the IgG levels produced by cow 1776 were particularly low.

The concentration of anti-Staph. aureus IgA in milk was also evaluated. Infection with MOK124 resulted in a higher concentration of specific IgA, with maximum titers observed at 168 hpi (Figure $4 \mathrm{C}$ ). A group $\times$ time interaction $(P<0.0001)$ and an overall group difference $(P=0.01)$ were detected. Higher IgA titers were observed in the MOK124 group than in the MOK023 group between 72 and 168 hpi.

\section{DISCUSSION}

Staphylococcus aureus is one of the most common causes of bovine mastitis in Ireland and worldwide, with specific lineages predominating in infection of the mammary gland. Previous in vitro studies have suggested that Staph. aureus expresses lineage-specific traits, which may influence the outcome of infection and induction of immune response (Zbinden et al., 2014; Bardiau et al., 2016; Budd et al., 2016). This is the first in vivo study in cattle that confirms that 2 Staph. aureus strains belonging to different lineages caused mastitis of different severity.

Few studies of intramammary challenge by multiple Staph. aureus strains have been published. A study by 

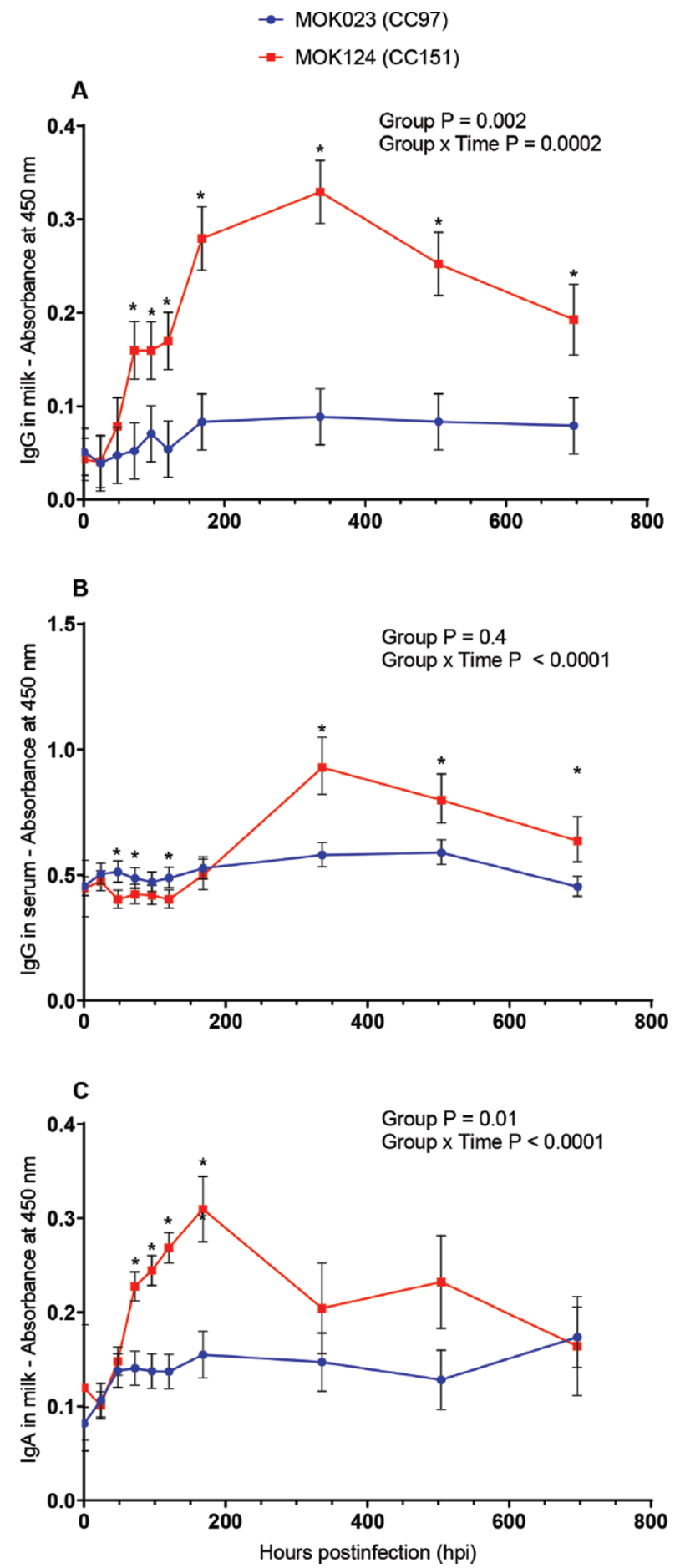

Figure 4. Effects of intramammary infection with Staphylococcus aureus strain MOK023 (blue circles) or MOK124 (red squares) on anti-Staph. aureus IgG in milk from infected quarters (A; LSM \pm SEM) and in serum (B; LSM $\pm 95 \%$ CI), and on anti-Staph. aureus IgA in milk from infected quarters $(\mathrm{C} ; \mathrm{LSM} \pm \mathrm{SEM}) . \mathrm{CC}=$ clonal complex. IgG and IgA titers were determined by ELISA, using wells coated with heat-killed MOK124. Data were analyzed using a MIXED model in SAS (SAS Institute Inc., Cary, NC) with time as a repeated measure. Overall $P$-values for between-group differences and for the group $\times$ time interaction are denoted on the graph. Significant differences between groups $(P<0.05)$ at each time point are marked with *
Atalla et al. (2009) compared N305 to strain 3231 as well as their small colony variants. The IMI with small colony variants resulted in less inflammation than that with the parent strains. However, the genotype of strain 3221 is unknown (Atalla et al., 2008), which makes further comparison difficult. A study by Vrieling et al. (2016), using 3 strains of unreported ST, associated the severity of clinical signs in cows with the ability of the infecting strain to secrete the LukMF' toxin.

Studies of Staph. aureus IMI commonly use strain N305 (Schukken et al., 1999; Alluwaimi et al., 2003; Bannerman et al., 2004, 2008; Atalla et al., 2009; Reinhardt et al., 2013), which belongs to CC97. Within CC97, N305 belongs to ST115, which is not a common ST isolated from mastitis cases, and has been proposed to be an extramammary organism associated with teat skin (Smith et al., 2005). Our study gives significant insight into mastitis caused by a CC97 strain that was recently recovered from a case of clinical mastitis and was a common genotype on that farm, indicating contagious spread (Budd et al., 2015). The outcome of infection with MOK023 is similar to that observed in studies on N305, which also tended to cause mild and chronic mastitis.

Staphylococcus aureus CC151 strains are common causes of mastitis in Ireland (Budd et al., 2015) and worldwide (Smith et al., 2005; Smyth et al., 2009; Schlotter et al., 2012; Pichette-Jolette et al., 2019). Two studies with a CC151 strain, RF122, have been reported. In the study by Wilson (2011), bacteria were inoculated into the teat canal; however, the trial was cut short due to the development of severe clinical signs. However, although the dosage used was very low (2 to $10 \mathrm{cfu}$ ), the bacteria were delivered into the teat canal in $10 \mathrm{~mL}$ of PBS. The large volume may have enabled the bacteria to be delivered directly into the gland cistern. In the second study by Wilson et al. (2018), 4 cows were challenged with $5 \times 10^{7} \mathrm{cfu} /$ $\mathrm{mL}$ of RF122 by teat dipping twice daily for up to $5 \mathrm{~d}$ and monitored for $21 \mathrm{~d}$. Three of the 4 infected animals developed clinical mastitis. Our study achieved infection in 6 of 7 animals after a single inoculation of MOK124, and 2 of 7 animals developed severe clinical mastitis. However, it is important to note that cows used in this study were in their first lactation, with a very low pre-infection SCC. In cows of higher parity or SCC, larger doses may be needed to achieve IMI, as it has been previously reported that cows with a lower pre-challenge SCC were more likely to become infected when challenged with Staph. aureus (Schukken et al., 1999).

In this study, cows challenged with MOK124 received a higher inoculum of Staph. aureus than did cows challenged with MOK023. However, infection with 
MOK124 was also established with $2.9 \times 10^{2}$ cfu in a pilot study, and this caused clinical mastitis in 1 of 2 cows (Niedziela, 2019). Inocula below 100 cfu of N305 were used to successfully establish infection in other studies (Bannerman et al., 2004, 2008). Generally, inocula used in other studies varied greatly, from $56 \mathrm{cfu}$ (Kauf et al., 2007) to 5,000 cfu (Atalla et al., 2009) of N305, and ranging from $50 \mathrm{cfu}$ (Allard et al., 2013) to $5 \times 10^{6}$ cfu (Petzl et al., 2016) when other strain types were used. Most of these studies did not report clinical signs in the infected animals, unless multiple quarters were inoculated. On the other hand, in a pilot study with RF122, clinical signs were observed with as few as $2 \mathrm{cfu}$ (Wilson, 2011). Furthermore, a study by Poutrel et al. (1978) examined whether infections could be established by various inocula of Staph. aureus (between 5 to $>150 \mathrm{cfu}$ ) and concluded that the type of infection caused and the ability to cause persistent infections were not dependent on the inoculum dose. Therefore, the differing host responses to MOK023 and MOK124 can likely be attributed to the genotype and virulence traits of the strain and not to the inoculum dose.

After pathogen entry into the udder, gram-positive bacteria are generally recognized by toll-like receptor 2 , and this stimulates production of cytokines and chemokines by the epithelial cells of the mammary gland through the activation of NF- $\kappa \mathrm{B}$ and subsequent neutrophil recruitment (Oviedo-Boyso et al., 2007). However, in response to Staph. aureus IMI, toll-like receptor 2-mediated signaling was reported to be inhibited (Günther et al., 2017). Furthermore, it has been reported that pro-inflammatory cytokines such as IL-1 $\beta$ and TNF- $\alpha$ were absent from milk of cows infected with Staph. aureus or were detected only at very low levels (Riollet et al., 2000; Bannerman et al., 2004). A variety of Staph. aureus strains were used in the above studies: strain N305 from CC97 (Bannerman et al., 2004), a strain belonging to ST8 (Günther et al., 2017), and an uncharacterized strain (Riollet et al., 2000). Selected markers of the innate and adaptive immune response to 2 genotypically distinct Staph. aureus strains were evaluated in the current study. In our study MOK023 (CC97) did not cause IL-1 $\beta$ secretion, consistent with the findings of Bannerman et al. (2004); however, IL-1 $\beta$ production was evident in response to MOK124 (CC151). The lack of in vivo studies including CC151 strains may explain why Staph. aureus is typically considered to cause a low immune response (Bannerman et al., 2004) and to have a minimal effect on milk yield or temperature (Benjamin et al., 2015).

Little is known about the protective effects of antibodies to Staph. aureus (Karauzum and Datta, 2017). In our study, a higher IgG antibody concentration in serum and milk and a higher IgA concentration in milk were recorded for MOK124-infected cows compared with MOK023-infected cows. The anti-Staph. aureus IgG levels in milk in the MOK124 group began to increase as early as $72 \mathrm{hpi}$, potentially due to exudation of plasma into the mammary gland rather than to antibody production in milk (Rainard et al., 2018). Reaching the maximum IgG levels in milk and serum at 2 wk post-infection in both groups is indicative of a primary antibody response and suggests that the animals were not previously exposed to intramammary Staph. aureus. In a study by Benjamin et al. (2015) maximum anti-Staph. aureus IgG concentration in both whey and plasma of Staph. aureus-infected cows was reached at 12 d post-infection. Similar to our study, the antibody response did not result in clearance of the pathogen.

A previous study of anti-Staph. aureus IgA secreted during IMI found no anti-Staph. aureus IgA in the serum of infected animals, and anti-Staph. aureus IgA was only found in milk of quarters from which Staph. aureus was recovered at the time (Leitner et al., 2000). In our study, anti-Staph. aureus IgA levels in milk from both groups reached their maximum levels $1 \mathrm{wk}$ post-infection, as opposed to $\operatorname{IgG}$, which reached its maximum levels 2 wk post-infection.

The results of this in vivo study contrasted with those of an in vitro study involving MOK023 and MOK124 (Murphy et al., 2019), where challenge of bMEC with MOK023 caused a high and rapid increase in expression of chemokines and pro-inflammatory mediators sufficient for neutrophil chemotaxis, whereas challenge with MOK124 caused a lower upregulation of gene expression and did not result in neutrophil chemotaxis. Therefore, it was expected that IMI with MOK023 would lead to higher production of pro-inflammatory mediators and a subsequent recruitment of somatic cells in vivo, at least initially. The lack of clinical or subclinical signs of mastitis in cows infected with MOK023 suggests that this strain does not trigger comparable initial signals to MOK124, as bacterial load was similar between both strains. This may be partially attributable to the fact that MOK023 internalizes within bMEC to a greater extent than MOK124 does (Murphy et al., 2019). A recent transcriptomics study of IMI with an ST8 strain of Staph. aureus highlighted inhibition of the innate immune response and simultaneous rearrangement of the cytoskeleton in host cells as differentially expressed pathways, suggesting that internalization of bacteria into the epithelial cells of the mammary gland was occurring at early stages of infection (Günther et al., 2017). However, it is also possible that early immune signaling by bMEC in response to infection with MOK023 could have contributed to control of proliferation of this 
strain. Rapid cytokine upregulation, as early as $3 \mathrm{hpi}$, was observed in bMEC in vitro in response to CC97 strains including MOK023 (Murphy et al., 2019). The ability of MOK124 to cause severe clinical mastitis may alternatively be related to toxin production: MOK124 carries genes for the LukMF' leukocidin (Budd et al., 2015), the level of which in milk has been previously associated with mastitis severity (Vrieling et al., 2016). Further, MOK023 and MOK124 also differ in their ability to form biofilm in vitro (Budd et al., 2016), a trait previously associated with clinical presentation of IMI.

Strain-specific virulence traits of Staph. aureus and their outcome on the course of human infection have also been investigated. Virulence factors such as cytolytic toxicity and biofilm formation influence the outcome of bacteremia caused by CC22 strains, but not by CC30 strains, suggesting that different Staph. aureus lineages may have developed different strategies to overcome host responses (Recker et al., 2017). Furthermore, strain-specific virulence has been observed in other bacterial species, such as Mycobacterium bovis (Jensen et al., 2018) and Escherichia coli (Goldstone et al., 2016; Blum et al., 2017, 2018). Further investigation of the strategies to overcome the host immune response used by specific strains and lineages within bacterial species will be necessary in the future. If the severity of disease can be predicted based on bacterial genotype, this may enable better prediction of disease outcome and therefore inform decisions about treatment or culling of infected animals.

A limitation of this study was the fact that the cows were not sampled more than once before challenge. Although all animals had a low SCC, it is possible that 1 or more could already have been infected with Staph. aureus. Although we believe that previous infection is unlikely, ideally sampling and culture of milk on 3 occasions at weekly intervals before challenge should have been completed.

This is the first study that compares the ability of 2 well-characterized strains of Staph. aureus from different bovine-adapted lineages to cause IMI. Significant differences $(P<0.05)$ in disease presentation and the immune response of cows to MOK124 and MOK023 were detected, with severe clinical mastitis observed in response to MOK124 only. Meanwhile, the low average SCC in MOK023-infected cows revealed a potential challenge for the farmer in detecting an infection with this strain, which might allow the strain to be transmitted to other animals in the herd and may potentially cause more severe disease should the animal become immunocompromised. Early lactation is when cows are most immunocompromised and likely to develop masti- tis (Breen et al., 2009), and should MOK023 persist in the udder through the dry period, a possibility exists that the infection might flare up in the next lactation.

In this study we have demonstrated that differences in mastitis outcome occur in response to 2 strains of Staph. aureus originating from different lineages. Therefore, studies of single strains may not be generalizable to all strains of Staph. aureus. Genotyping strains with a standardized method such as multi-locus sequence typing would greatly assist in comparison of results across studies. A need for better detection options for Staph. aureus IMI may exist, as illustrated by the low SCC induced by the MOK023 strain. Lower SCC limits may need to be used to classify healthy animals. To assist strain-specific detection of bovine mastitis, pen-side genotyping of the infecting organism may be helpful in the future.

\section{ACKNOWLEDGMENTS}

This study would not have been possible without the invaluable help of the farm staff of University College Dublin (UCD) Lyons Research Farm (Lyons Estate, Co. Kildare, Ireland), including Eddie Jordan, Michael Clarke, Joseph Callanan, and Michael McDonald. Mary Duane, Herd Health and Animal Husbandry, UCD School of Veterinary Medicine, selected the animals for the trial. We thank Margaret Murray of Teagasc Grange (Dunsany, Ireland) for assistance with milk slide preparations and milk ELISA, Jim Flynn of Teagasc Moorepark (Moorepark West, Ireland) for SCC measurements, and Peter O'Brien of the UCD School of Veterinary Medicine for advice on milk slide preparation and milk cell identification. We gratefully acknowledge grant support from the Department of Agriculture, Food and the Marine of Ireland (14/S/802; Dublin). Dagmara A. Niedziela participated in the in vivo challenge experiment, optimized and conducted the laboratory-based work, analyzed the data, and drafted the manuscript. Mark P. Murphy participated in the in vivo challenge experiment, optimized and conducted the laboratory-based work, and drafted the manuscript. Orla M. Keane designed and conducted the in vivo challenge experiment, conceived the initial idea of the study, and participated in its design and coordination. Finola C. Leonard designed and conducted the in vivo challenge experiment, conceived the initial idea of the study, and participated in study design and coordination. Jim Grant supervised statistical analysis of the data. All authors helped to draft the manuscript and read and approved the final manuscript. The authors have not stated any conflicts of interest. 


\section{REFERENCES}

AHI (Animal Health Ireland) Cell Check Technical Working Group. 2011. CellCheck Farm Guidelines for Mastitis Control. Version 1. AHI, Carrick-on-Shannon, Ireland.

Allard, M., C. Ster, C. L. Jacob, D. Scholl, M. S. Diarra, P. Lacasse, and F. Malouin. 2013. The expression of a putative exotoxin and an $\mathrm{ABC}$ transporter during bovine intramammary infection contributes to the virulence of Staphylococcus aureus. Vet. Microbiol. 162:761-770. https://doi.org/10.1016/j.vetmic.2012.09.029.

Alluwaimi, A. M., C. M. Leutenegger, T. B. Farver, P. V. Rossitto, W. L. Smith, and J. S. Cullor. 2003. The cytokine markers in Staphylococcus aureus mastitis of bovine mammary gland. J. Vet. Med. B Infect. Dis. Vet. Public Health 50:105-111. https://doi.org/10 .1046/j.1439-0450.2003.00628.x.

Atalla, H., C. Gyles, C. L. Jacob, H. Moisan, F. Malouin, and B. Mallard. 2008. Characterization of a Staphylococcus aureus small colony variant (SCV) associated with persistent bovine mastitis. Foodborne Pathog. Dis. 5:785-799. https://doi.org/10.1089/fpd 2008.0110.

Atalla, H., C. Gyles, B. Wilkie, K. Leslie, and B. Mallard. 2009. Somatic cell scores and clinical signs following experimental intramammary infection of dairy cows with a Staphylococcus aureus small colony variant $(S$. aureus $\mathrm{SCV}$ ) in comparison to other bovine strains. Vet. Microbiol. 137:326-334. https://doi.org/10.1016/j .vetmic.2009.01.027.

Bannerman, D. D., M. J. Paape, J. W. Lee, X. Zhao, J. C. Hope, and P. Rainard. 2004. Escherichia coli and Staphylococcus aureus elicit differential innate immune responses following intramammary infection. Clin. Diagn. Lab. Immunol. 11:463-472. https://doi.org/ 10.1128/CDLI.11.3.463-472.2004.

Bannerman, D. D., H. R. Springer, M. J. Paape, A. C. Kauf, and J. P. Goff. 2008. Evaluation of breed-dependent differences in the innate immune responses of Holstein and Jersey cows to Staphylococcus aureus intramammary infection. J. Dairy Res. 75:291-301. https:/ /doi.org/10.1017/S0022029908003427.

Bardiau, M., J. Caplin, J. Detilleux, H. Graber, P. Moroni, B. Taminiau, and J. G. Mainil. 2016. Existence of two groups of Staphylococcus aureus strains isolated from bovine mastitis based on biofilm formation, intracellular survival, capsular profile and agr-typing. Vet. Microbiol. 185:1-6. https://doi.org/10.1016/j.vetmic.2016.01 .003 .

Barkema, H. W., Y. H. Schukken, T. J. G. M. Lam, M. L. Beiboer, H. Wilmink, G. Benedictus, and A. Brand. 1998. Incidence of clinical mastitis in dairy herds grouped in three categories by bulk milk somatic cell counts. J. Dairy Sci. 81:411-419. https://doi.org/10 .3168/jds.S0022-0302(98)75591-2.

Barlow, J. W., R. N. Zadoks, and Y. H. Schukken. 2013. Effect of lactation therapy on Staphylococcus aureus transmission dynamics in two commercial dairy herds. BMC Vet. Res. 9:28. https://doi.org/ 10.1186/1746-6148-9-28.

Barrett, D. J., A. M. Healy, F. C. Leonard, and M. L. Doherty. 2005. Prevalence of pathogens causing subclinical mastitis in 15 dairy herds in the Republic of Ireland. Ir. Vet. J. 58:333-337. https:// doi.org/10.1186/2046-0481-58-6-333.

Benjamin, A. L., B. B. Green, L. R. Hayden, J. W. Barlow, and D. E. Kerr. 2015. Cow-to-cow variation in fibroblast response to a toll-like receptor $2 / 6$ agonist and its relation to mastitis caused by intramammary challenge with Staphylococcus aureus. J. Dairy Sci. 98:1836-1850. https://doi.org/10.3168/jds.2014-9075.

Blum, S. E., R. J. Goldstone, J. P. R. Connolly, M. Reperant-Ferter, P. Germon, N. F. Inglis, O. Krifucks, S. Mathur, E. Manson, K. McLean, P. Rainard, A. J. Roe, G. Leitner, and D. G. E. Smith. 2018. Postgenomics characterization of an essential genetic determinant of mammary pathogenic Escherichia coli. MBio 9:e0042318. https://doi.org/10.1128/mBio.00423-18.

Blum, S. E., E. D. Heller, S. Jacoby, O. Krifucks, and G. Leitner. 2017. Comparison of the immune responses associated with experimental bovine mastitis caused by different strains of Escherichia coli. J. Dairy Res. 84:190-197. https://doi.org/10.1017/ S0022029917000206.
Breen, J. E., M. J. Green, and A. J. Bradley. 2009. Quarter and cow risk factors associated with the occurrence of clinical mastitis in dairy cows in the United Kingdom. J. Dairy Sci. 92:2551-2561. https://doi.org/10.3168/jds.2008-1369.

Brightling, P. B., R. D. Dyson, A. F. Hope, and J. Penry. 2009. A national programme for mastitis control in Australia: Countdown Downunder. Irish Vet. J. 62(Suppl.):S52-S58. https://doi.org/10 .1186/2046-0481-62-S4-S52.

Budd, K. E., F. McCoy, S. Monecke, P. Cormican, J. Mitchell, and O. M. Keane. 2015. Extensive genomic diversity among bovine-adapted Staphylococcus aureus: Evidence for a genomic rearrangement within CC97. PLoS One 10:e0134592. https://doi.org/10.1371/ journal.pone.0134592.

Budd, K. E., J. Mitchell, and O. M. Keane. 2016. Lineage associated expression of virulence traits in bovine-adapted Staphylococcus aureus. Vet. Microbiol. 189:24-31. https://doi.org/10.1016/j.vetmic 2016.04.013.

Cronin, J. G., R. Hodges, S. Pedersen, and I. M. Sheldon. 2015. Enzyme linked immunosorbent assay for quantification of bovine interleukin-8 to study infection and immunity in the female genital tract. Am. J. Reprod. Immunol. 73:372-382. https://doi.org/10 $.1111 /$ aji.12344.

Enright, M. C., N. P. J. Day, C. E. Davies, S. J. Peacock, and B. G. Spratt. 2000. Multilocus sequence typing for characterization of methicillin-resistant and methicillin-susceptible clones of Staphylococcus aureus. J. Clin. Microbiol. 38:1008-1015. https://doi.org/10 .1128/JCM.38.3.1008-1015.2000.

Geary, U., N. Lopez-Villalobos, B. O'Brien, D. J. Garrick, and L. Shalloo. 2014. Estimating the impact of somatic cell count on the value of milk utilising parameters obtained from the published literature. J. Dairy Res. 81:223-232. https://doi.org/10.1017/ S0022029914000053.

Goldstone, R. J., S. Harris, and D. G. Smith. 2016. Genomic content typifying a prevalent clade of bovine mastitis-associated Escherichia coli. Sci. Rep. 6:30115. https://doi.org/10.1038/srep30115.

Günther, J., M. Koy, A. Berthold, H. J. Schuberth, and H. M. Seyfert. 2016. Comparison of the pathogen species-specific immune response in udder derived cell types and their models. Vet. Res. 47:22. https://doi.org/10.1186/s13567-016-0307-3.

Günther, J., W. Petzl, I. Bauer, S. Ponsuksili, H. Zerbe, H. J. Schuberth, R. M. Brunner, and H. M. Seyfert. 2017. Differentiating Staphylococcus aureus from Escherichia coli mastitis: S. aureus triggers unbalanced immune-dampening and host cell invasion immediately after udder infection. Sci. Rep. 7:4811. https://doi.org/ 10.1038/s41598-017-05107-4.

Halasa, T., K. Huijps, O. Osteras, and H. Hogeveen. 2007. Economic effects of bovine mastitis and mastitis management: A review. Vet. Q. 29:18-31. https://doi.org/10.1080/01652176.2007.9695224.

Jensen, K., I. J. Gallagher, N. Johnston, M. Welsh, R. Skuce, J. L. Williams, and E. J. Glass. 2018. Variation in the early host-pathogen interaction of bovine macrophages with divergent Mycobacterium bovis strains in the United Kingdom. Infect. Immun. 86:e00385-17.

Karauzum, H., and S. K. Datta. 2017. Adaptive immunity against Staphylococcus aureus. Pages 419-439 in Staphylococcus aureus: Microbiology, Pathology, Immunology, Therapy and Prophylaxis. F. Bagnoli, R. Rappuoli, and G. Grandi, ed. Springer International Publishing, Cham, Switzerland.

Kauf, A. C. W., R. F. Rosenbusch, M. J. Paape, and D. D. Bannerman. 2007. Innate immune response to intramammary Mycoplasma bovis infection. J. Dairy Sci. 90:3336-3348. https://doi.org/10 .3168/jds.2007-0058.

Keane, O. M., K. E. Budd, J. Flynn, and F. McCoy. 2013. Pathogen profile of clinical mastitis in Irish milk-recording herds reveals a complex aetiology. Vet. Rec. 173:17. https://doi.org/10.1136/vr .101308 .

Leitner, G., B. Yadlin, A. Glickman, M. Chaffer, and A. Saran. 2000. Systemic and local immune response of cows to intramammary infection with Staphylococcus aureus. Res. Vet. Sci. 69:181-184. https://doi.org/10.1053/rvsc.2000.0409.

Murphy, M. P., D. A. Niedziela, F. C. Leonard, and O. M. Keane. 2019. The in vitro host cell immune response to bovine-adapted 
Staphylococcus aureus varies according to bacterial lineage. Sci. Rep. 9:6134. https://doi.org/10.1038/s41598-019-42424-2.

Niedziela, D. A. 2019. Strain specific virulence of Staphylococcus aureus. PhD thesis, School of Veterinary Medicine, University College Dublin, Dublin, Ireland.

Østerås, O., and L. Sølverød. 2009. Norwegian mastitis control programme. Ir. Vet. J. 62(Suppl. 4):S26-S33. https://doi.org/10 .1186/2046-0481-62-S4-S26.

Østerås, O., L. Sølverød, and O. Reksen. 2006. Milk culture results in a large Norwegian survey - Effects of season, parity, days in milk, resistance, and clustering. J. Dairy Sci. 89:1010-1023. https://doi .org/10.3168/jds.S0022-0302(06)72167-1.

Oviedo-Boyso, J., J. J. Valdez-Alarcon, M. Cajero-Juarez, A. OchoaZarzosa, J. E. Lopez-Meza, A. Bravo-Patino, and V. M. BaizabalAguirre. 2007. Innate immune response of bovine mammary gland to pathogenic bacteria responsible for mastitis. J. Infect. 54:399409. https://doi.org/10.1016/j.jinf.2006.06.010.

Persson, Y., A. K. Nyman, and U. Gronlund-Andersson. 2011. Etiology and antimicrobial susceptibility of udder pathogens from cases of subclinical mastitis in dairy cows in Sweden. Acta Vet. Scand. 53:36. https://doi.org/10.1186/1751-0147-53-36.

Petzl, W., J. Gunther, K. Muhlbauer, H. M. Seyfert, H. J. Schuberth, J. Hussen, C. Sauter-Louis, A. Hafner-Marx, and H. Zerbe. 2016. Early transcriptional events in the udder and teat after intra-mammary Escherichia coli and Staphylococcus aureus challenge. Innate Immun. 22:294-304. https://doi.org/10.1177/1753425916640057.

Petzl, W., H. Zerbe, J. Günther, W. Yang, H.-M. Seyfert, G. Nürnberg, and H.-J. Schuberth. 2008. Escherichia coli, but not Staphylococcus aureus triggers an early increased expression of factors contributing to the innate immune defense in the udder of the cow. Vet. Res. 39:18. https://doi.org/10.1051/vetres:2007057.

Pichette-Jolette, S., G. Millette, E. Demontier, D. Bran-Barrera, M. Cyrenne, C. Ster, D. Haine, G. Keefe, F. Malouin, and J. P. Roy. 2019. Partial prediction of the duration and the clinical status of Staphylococcus aureus bovine intramammary infections based on the phenotypic and genotypic analysis of isolates. Vet. Microbiol. 228:188-195. https://doi.org/10.1016/j.vetmic.2018.11.024.

Poutrel, B., C. Lerondelle, and M. Ducelliez. 1978. Induced staphylococcal infections in the bovine mammary gland. Annales de Recherches Vétérinaires, INRA Editions 9:119-128. Institut National de la Recherche Agronomique (INRA), Paris, France.

Rainard, P., G. Foucras, J. R. Fitzgerald, J. Watts, G. Koop, and J. Middleton. 2018. Knowledge gaps and research priorities in Staphylococcus aureus mastitis control. Transbound. Emerg. Dis. 65:149-165. https://doi.org/10.1111/tbed.12698.

Recker, M., M. Laabei, M. S. Toleman, S. Reuter, R. B. Saunderson, B. Blane, M. E. Torok, K. Ouadi, E. Stevens, M. Yokoyama, J. Steventon, L. Thompson, G. Milne, S. Bayliss, L. Bacon, S. J. Peacock, and R. C. Massey. 2017. Clonal differences in Staphylococcus aureus bacteraemia-associated mortality. Nat. Microbiol. 2:1381-1388. https://doi.org/10.1038/s41564-017-0001-x.

Reinhardt, T. A., R. E. Sacco, B. J. Nonnecke, and J. D. Lippolis 2013. Bovine milk proteome: Quantitative changes in normal milk exosomes, milk fat globule membranes and whey proteomes resulting from Staphylococcus aureus mastitis. J. Proteomics 82:141-154. https://doi.org/10.1016/j.jprot.2013.02.013.

Riollet, C., P. Rainard, and B. Poutrel. 2000. Differential induction of complement fragment C5a and inflammatory cytokines during intramammary infections with Escherichia coli and Staphylococcus aureus. Clin. Diagn. Lab. Immunol. 7:161-167. https://doi.org/10 .1128/CDLI.7.2.161-167.2000.

Roland, L., M. Drillich, and M. Iwersen. 2014. Hematology as a diagnostic tool in bovine medicine. J. Vet. Diagn. Invest. 26:592-598. https://doi.org/10.1177/1040638714546490.

Rollin, E., K. C. Dhuyvetter, and M. W. Overton. 2015. The cost of clinical mastitis in the first 30 days of lactation: An economic modeling tool. Prev. Vet. Med. 122:257-264. https://doi.org/10.1016/j .prevetmed.2015.11.006.

Ruijter, J. M., H. H. Thygesen, O. J. Schoneveld, A. T. Das, B. Berkhout, and W. H. Lamers. 2006. Factor correction as a tool to eliminate between-session variation in replicate experiments: Application to molecular biology and retrovirology. Retrovirology $3: 2$. https://doi.org/10.1186/1742-4690-3-2.

Schlotter, K., R. Ehricht, H. Hotzel, S. Monecke, M. Pfeffer, and K. Donat. 2012. Leukocidin genes lukF-P83 and lukM are associated with Staphylococcus aureus clonal complexes 151, 479 and 133 isolated from bovine udder infections in Thuringia, Germany. Vet. Res. 43:42. https://doi.org/10.1186/1297-9716-43-42.

Schukken, Y. H., K. E. Leslie, D. A. Barnum, B. A. Mallard, J. H. Lumsden, P. C. Dick, G. H. Vessie, and M. E. Kehrli. 1999. Experimental Staphylococcus aureus intramammary challenge in late lactation dairy cows: Quarter and cow effects determining the probability of infection. J. Dairy Sci. 82:2393-2401. https://doi .org/10.3168/jds.S0022-0302(99)75490-1.

Smith, E. M., L. E. Green, G. F. Medley, H. E. Bird, L. K. Fox, Y H. Schukken, J. V. Kruze, A. J. Bradley, R. N. Zadoks, and C. G. Dowson. 2005. Multilocus sequence typing of intercontinental bovine Staphylococcus aureus isolates. J. Clin. Microbiol. 43:47374743. https://doi.org/10.1128/JCM.43.9.4737-4743.2005.

Smyth, D. S., E. J. Feil, W. J. Meaney, P. J. Hartigan, T. Tollersrud, J. R. Fitzgerald, M. C. Enright, and C. J. Smyth. 2009. Molecular genetic typing reveals further insights into the diversity of animalassociated Staphylococcus aureus. J. Med. Microbiol. 58:1343-1353. https://doi.org/10.1099/jmm.0.009837-0.

Snedecor, G. W., and W. G. Cochran. 1989. Statistical Methods. 8th ed. Iowa State University Press, Ames, IA.

Ster, C., V. Lebeau, J. Leclerc, A. Fugère, K. A. Veh, J.-P. Roy, and F. Malouin. 2017. In vitro antibiotic susceptibility and biofilm production of Staphylococcus aureus isolates recovered from bovine intramammary infections that persisted or not following extended therapies with cephapirin, pirlimycin or ceftiofur. Vet. Res. 48:56. https://doi.org/10.1186/s13567-017-0463-0.

Vrieling, M., E. M. Boerhout, G. F. van Wigcheren, K. J. Koymans, T. G. Mols-Vorstermans, C. J. C. de Haas, P. C. Aerts, I. J. J. M. Daemen, K. P. M. van Kessel, A. P. Koets, V. P. M. G. Rutten, P. J. M. Nuijten, J. A. G. van Strijp, and L. Benedictus. 2016. LukMF' is the major secreted leukocidin of bovine Staphylococcus aureus and is produced in vivo during bovine mastitis. Sci. Rep. 6:37759. https://doi.org/10.1038/srep37759.

Wilson, G. J., S. W. Tuffs, B. A. Wee, K. S. Seo, N. Park, T. Connelley, C. M. Guinane, W. I. Morrison, and J. R. Fitzgerald. 2018. Bovine Staphylococcus aureus superantigens stimulate the entire T cell repertoire of cattle. Infect. Immun. 86:e0505-18. https://doi .org/10.1128/IAI.00505-18.

Wilson, G. J. C. 2011. Genome scale analysis of the role of superantigens in Staphylococcus aureus disease pathogenesis. $\mathrm{PhD}$ thesis. Royal (Dick) School of Veterinary Studies, University of Edinburgh, Edinburgh, Scotland.

Zadoks, R. N., H. G. Allore, H. W. Barkema, O. C. Sampimon, G. J. Wellenberg, Y. T. Gröhn, and Y. H. Schukken. 2001. Cow- and quarter-level risk factors for Streptococcus uberis and Staphylococcus aureus mastitis. J. Dairy Sci. 84:2649-2663. https://doi.org/10 .3168/jds.S0022-0302(01)74719-4.

Zbinden, C., R. Stephan, S. Johler, N. Borel, J. Bünter, R. M. Bruckmaier, and O. Wellnitz. 2014. The inflammatory response of primary bovine mammary epithelial cells to Staphylococcus aureus strains is linked to the bacterial phenotype. PLoS One 9:e87374. https://doi.org/10.1371/journal.pone.0087374.

\section{ORCIDS}

Dagmara A. Niedziela @ https://orcid.org/0000-0003-1149-3923 Mark P. Murphy (1) https://orcid.org/0000-0001-5624-1338 Jim Grant () https://orcid.org/0000-0003-1400-1859

Orla M. Keane ๑ https://orcid.org/0000-0002-9507-2191 Finola C. Leonard ๑ https://orcid.org/0000-0001-6651-0482 